University of Nebraska - Lincoln

DigitalCommons@University of Nebraska - Lincoln

$1-4-2021$

\title{
Will Seasonality Patterns for Beef Export Sales and Commitments Hold in 2021?
}

Elliott James Dennis

University of Nebraska - Lincoln, elliott.dennis@unl.edu

Follow this and additional works at: https://digitalcommons.unl.edu/ageconfarmmgmt

Part of the Agribusiness Commons, Entrepreneurial and Small Business Operations Commons, Management Information Systems Commons, Other Business Commons, and the Other Economics Commons

Dennis, Elliott James, "Will Seasonality Patterns for Beef Export Sales and Commitments Hold in 2021?" (2021). Extension Farm and Ranch Management. 57.

https://digitalcommons.unl.edu/ageconfarmmgmt/57

This Article is brought to you for free and open access by the Agricultural Economics Department at DigitalCommons@University of Nebraska - Lincoln. It has been accepted for inclusion in Extension Farm and Ranch Management by an authorized administrator of DigitalCommons@University of Nebraska - Lincoln. 


\section{Will Seasonality Patterns for Beef Export Sales and Commitments Hold in 2021?}

Elliott Dennis, assistant professor and livestock extension economist, University of NebraskaLincoln

January 4, 2021

This article was first published by In the Cattle Markets

Trade occurs when price differences between the two locations are large enough after accounting for transportation cost, exchange rates, tariffs, etc. Exports vary throughout the year since prices reflect current and future supply and demand situations. Seasonality in cattle production, meat demand, and market disruptions are some examples of why wholesale beef prices increase and decrease within a year.

The inability to market cattle in the second quarter of 2020 and increased demand for retail beef products due to government gathering restrictions in restaurants caused wholesale beef prices to rise to historical levels. Beef wholesalers can choose to market beef to the domestic market (retail or food service) or the export market. So how did higher domestic wholesale beef prices impact beef export sales and commitments in 2020? Likewise, knowing how the market worked through supply and demand disruptions in 2020, what can we reasonably expect from export sales and commitments in 2021? These questions can be partially answered by looking at historical seasonal export sales and commitment patterns and comparing 2020 to years with large trade disruptions.

\section{Year-ending Beef Export Sales}

One way to monitor beef exports is through USDA-FAS's weekly export sales report. This report shows the number of beef exports, the cumulative exports in the current marketing year, previous sales that have not shipped during the current marketing year, previous sales planned for current marketing year but were cancelled, and sales scheduled to ship in future marketing years. Beef export data is reported weekly nationally and by each beef export partner. Table 1 displays the 2020 year ending beef export sales report for the top 10 trading countries. These countries accounted for $96 \%$ of all beef exports. Japan and Korea accounted for nearly $60 \%$ of all exports that were shipped. There can be a delay between when beef is purchased and shipped. The difference is classified as outstanding sales. On average across all countries, $11 \%$ of total commitments (i.e. shipped exports + outstanding sales) are outstanding sales. The People's Republic of China and Hong Kong have abnormally large outstanding sales, approximately 35\% of total commitments.

\section{Seasonal Patterns in Beef Exports}

From the weekly USDA-FAS data, one can aggregate to monthly averages and calculate beef export sales seasonal indices. These are useful in making pricing decisions, specifically forecasting prices, assessing pricing alternatives, and evaluating current market conditions. Higher indices indicate that quantities are relatively higher in that month compared to other months, and vis-versa. Variation in the index across years but within a month indicates how historically (in)consistent the index is. The standard deviation is one way to quantify this variation. A range of expected quantities can then be obtained by adding or subtracting one standard deviation from the seasonal index. This represents, in part, a historically reliable range 
of prices or quantities around the average price index in each month. Figure 1 plots the historical seasonal average from 2010-2019 and +/- one standard deviation. Historically, the first quarter has seasonally lower and more inconsistent export quantities than other quarters. Export quantities are the highest and most consistent in the second quarter. Local, domestic, and international changes in slaughter rates, supplies of substitute meat products, and consumer beef preferences all influence the domestic wholesale beef price and eventually each country's desire to import US beef.

\section{Comparing Export Seasonality Across Market Events: COVID-19 vs. BSE}

At the beginning of 2020, there was a large number of cattle that were set to be harvested in the first and second quarters. When meatpacking plants closed at the beginning of the second quarter there were a large number of cattle ready to be harvested in preparation for summer grilling. These closures caused a shortage of wholesale beef raising prices. Wholesale beef prices continued to rise with increased consumer retail meat purchases and the difficulty in repurposing meat destined for food service. Combined these events lowered export sales by approximately $40 \%$ in May and June compared to the 10-year average (see Figure 2). The beef market was eventually able to sort through the supply and demand issues and prices, and subsequently, export sales, seasonally normalized. At the end of 2020, beef export commitments were the largest ever and actual exports were the second-largest behind 2018.

Comparing the case of BSE in December of 2003 to COVID-19 shows how quickly the export market normalized to the effects of the pandemic. Figure 2 plots the seasonal index for the 10year average (2010-2019), BSE (2004), and COVID-19 (2020). In the first quarter of 2004, export sales were near zero as countries implemented trade restrictions. As more information emerged about the severity and spread of BSE export sales seasonally increased. Nominally, export sales fell from 64,000 to 11,500 between 2003 and 2004. The beef export sales did not reach pre-BSE levels until 2018, 15 years post-incident. Compare this to COVID-19 in 2020 where export sales only dipped in May and June and then rebounded. All remaining months in 2020 were within one standard deviation of the 10-year average. In other words, the variation in export sales after June was statistically normal.

\section{Export Sales and Commitments into 2021}

The beef industry is once again entering into 2021 with a near-record number of cattle on feed and marketings below a year ago. Both these indicate a large amount of meat will come to market in the first quarter of 2021. Historically, the number of beef export sales has been seasonally lower in the first quarter (see Figure 1). Since 2002, 2020 was the only time export sales were seasonally higher in the first quarter. Even correcting for lower export sales in May and June by setting them to their 10-year averages shows that 2020 first-quarter export sales had never seasonally occurred before. The domestic market likely needs to be the driver of working through wholesale meat supplies in the first quarter. Drawing from 2020, the market's ability to do so could be hindered by meatpacking plant shutdowns (recent example in Guelph, Canada) and government restrictions on social gatherings (increased restrictions in New York State). A positive is that the US-JPN, US-KOR, US-CHN, and USMCA trade deals are still in place for the time being. Whether we enter round 2 of the US-CHN trade deal and whether China exports already committed beef is more uncertain given the anticipated change in presidency this coming month. 


\section{Supporting Figures}

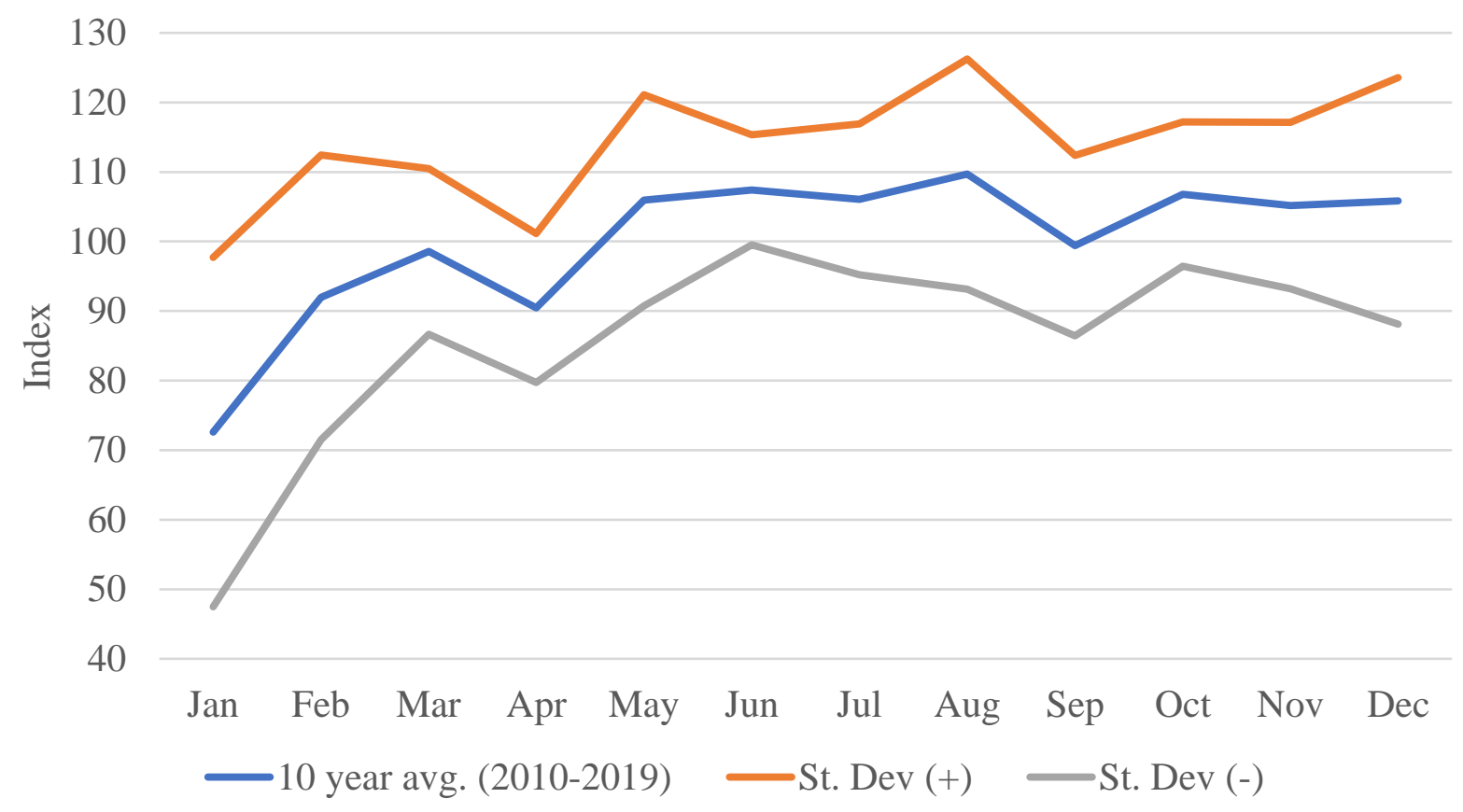

Figure 1. Historical Seasonality in Exports, 2010-2019

Source: From weekly export sales (USDA-FAS, 2020)

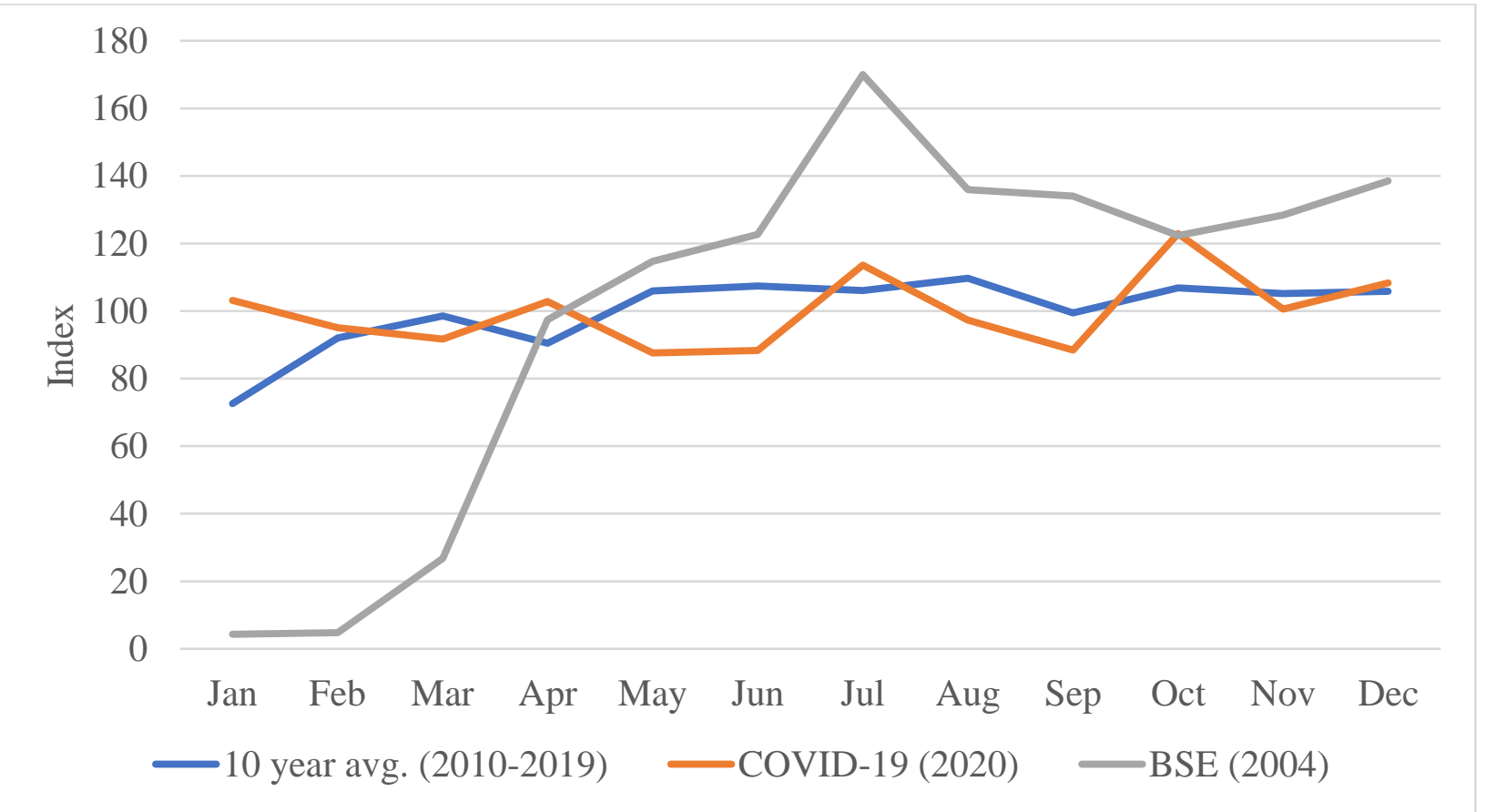

Figure 2. Comparing Seasonality Patterns in Exports Across Various Years

Source: From weekly export sales (USDA-FAS, 2020) 


\section{Supporting Tables}

Table 1. 2020 Year Ending Beef Exports, Outstanding Sales, and Total Commitment

\begin{tabular}{|c|c|c|c|c|c|c|}
\hline \multirow[b]{2}{*}{ Country } & \multirow[b]{2}{*}{$\begin{array}{l}\text { Shipped } \\
\text { Exports }\end{array}$} & \multirow[b]{2}{*}{$\begin{array}{c}\text { Outstanding } \\
\text { Sales }\end{array}$} & \multirow{2}{*}{$\begin{array}{c}\text { Current } \\
\text { Marketing Year } \\
\text { Total Commitment }\end{array}$} & \multirow{2}{*}{$\begin{array}{l}\text { Outstanding Sales } \\
\text { as a Percentage of } \\
\text { Total Commitments }\end{array}$} & \multicolumn{2}{|c|}{ Country's Share of: } \\
\hline & & & & & $\begin{array}{l}\text { Shipped } \\
\text { Exports }\end{array}$ & $\begin{array}{c}\text { Total } \\
\text { Commitments }\end{array}$ \\
\hline Japan & 258,188 & 20,488 & 278,676 & 7.35 & 30.75 & 29.30 \\
\hline Korea, Republic of & 231,200 & 14,855 & 246,055 & 6.04 & 27.54 & 25.87 \\
\hline Mexico & 72,126 & 5,089 & 77,215 & 6.59 & 8.59 & 8.12 \\
\hline Taiwan & 65,316 & 5,347 & 70,663 & 7.57 & 7.78 & 7.43 \\
\hline Hong Kong & 58,023 & 33,871 & 91,894 & 36.86 & 6.91 & 9.66 \\
\hline Canada & 50,236 & 3,778 & 54,014 & 6.99 & 5.98 & 5.68 \\
\hline China & 42,530 & 21,001 & 63,531 & 33.06 & 5.07 & 6.68 \\
\hline Indonesia & 12,485 & 1,526 & 14,011 & 10.89 & 1.49 & 1.47 \\
\hline Vietnam & 8,321 & 464 & 8,785 & 5.28 & 0.99 & 0.92 \\
\hline Philippines & 6,964 & 339 & 7,303 & 4.64 & 0.83 & 0.77 \\
\hline Top 10 Countries & 805,389 & 106,758 & 912,147 & 11.70 & 95.93 & 95.90 \\
\hline All Total & 839,641 & 111,390 & 951,031 & 11.71 & 100.00 & 100.00 \\
\hline
\end{tabular}

Source: USDA_FAS (2020) 